\title{
Regulatory Impact Assessment in Macedonia and Estonia: Lessons (to be) Learned
}

\author{
UDK: $354: 340.13$ \\ Marija Risteska \\ Centre for Research and Policy Making \\ risteska@crpm.org.mk
}

\section{ABSTRACT}

Considering that legislation (primary and secondary legislation) is the most commonly used instrument for policy-making, and that the state reached out to regulate more to improve the environment for doing business in the financial crises of 2008-2009, we look at the Regulatory Impact Assessment (hereinafter RIA), which is an important segment of the policy-making cycle allowing for identification of impact of laws on various segments of society including businesses. This policy analysis instrument has been employed in most the EU member states as well as in the countries that seek for EU accession such as Macedonia. Since RIA is at the early stage of development in Macedonia we have taken Estonia as a case study and identify the lessons Macedonia can learn from Estonia. The analysis shows that in Macedonia RIA was mostly conceived as part of an economic reform package and has resulted in RIA being confined to specific sectors instead of being made fully part of the general policy-making. The current system therefore still falls short of exploring the full potential of RIA as a tool for better regulation. Coordination of the RIA process, the extension of the scope as well as the methods for conducting RIA are some of the areas Macedonia can improve taking the example of Estonia.

Key words: EU, regulatory impact assessment, lessons learning, Estonia, Macedonia

JEL: HTO

\section{Introduction}

The regulatory impact assessment (hereinafter RIA) is a policy analysis tool envisioned to strengthen good governance in the countries applied.

Risteska, M. (201 1). Regulatory Impact Assessment in Macedonia and Estonia: 
Namely, the impact assessment requirement for all forms of intervention (including primary or secondary legislation as well as codes of practice or guidance) aims to identify what the effect will be of such legislation on environment, economy and society. However, in many countries the tool has been used to foresee whether the proposed legislation will increase or decrease costs. To this account there is a lively scholarly debate on whether this process has created a new mode of governance focused on the efficiency of markets (OECD, 2002) or, instead, a more subtle form of economic interventionism (as argued by Moran in 2003 in his account of British regulation).

The home of RIA is the USA. Radaelli (2005), however, argues that the idea of RIA traveled and its international diffusion has been remarkable. The major agent of transnational communication at the international level is the Organization for Economic Co-operation and Development (OECD). The diffusion was facilitated through its report on Regulatory Impact Analysis - Best Practices in OECD Countries from 1997. In the EU, there are specific bodies engaged with diffusion of the RIA, such as the Mandelkern Group ${ }^{1}$ - that prepared a report for the EU Laeken Summit of the European Council. Outside the EU, the Sigma agency - a joint initiative of the OECD and the EU, although eminently funded by Brussels - has promoted the adoption of impact assessment in countries willing to join the EU (Sigma, 2001).

Macedonia has been a candidate country for EU membership since 2005. The debate on introduction of RIA in the legislative drafting has been initiated by international finance institutions in the framework of their efforts for improvement of business environment, but was further stirred by the EU and facilitated through SIGMA in the context of reform of the pubic administration and building capacities for policy making. This paper evaluates the RIA model adopted by the Macedonian government and argues that it is predominantly focused on reducing administrative burdens to businesses in times of financial crises. It also compares it to Estonia where the RIA model is significantly different as well as applied in a more developed way. The analysis depicts the areas and lessons

1 The Mandelkern Group was formed by a Resolution of the Ministers of Public Administration which gave it the »mandate to develop a common method of evaluating the quality of regulation«. In 2001 the Mandelkern Group - the informal group of directors of better regulation programs and the "High-Level Group on Competitiveness" within the Competitiveness Council prepared an influential report on regulatory impact assessment. 
Macedonia can learn from Estonia in the process of design and implementation of RIA.

\section{Regulatory impact assessment as a tool for good governance - European experiences}

In the last decade most European governments were investing in programs for "better regulation" and "good regulatory governance" (OECD, 2002). RIA is the cornerstone of these programs ${ }^{2}$. The RIA is foreseen as a tool through which one of the goals outlined in the Lisbon strategy will be achieved - to make Europe the most competitive knowledge-based society of the world by 2010. The diffusion of RIA happened really swiftly. Since $2004^{3}$ when four finance ministers from Ireland, the Netherlands, Luxembourg, and the UK committed four successive European Union (EU) Presidencies to "further enhance the quality of impact assessments" at the EU level and introduce "effective systems of impact assessment for new legislation and simplification programs" at member state level, until today when all EU members as well as the countries which aspire for EU membership have either formally introduced RIA or are in the process to do so.

As Claudio Radaelli (2005) argues ithe pivotal position of RIA stems from the fact that it provides standards for the whole process of policy formulation, by showing how consultation, the socio-economic costs and benefits, and the major trade-offs in policy choice have been taken into account in the assessment of regulatory proposals or in the analysis of existing legislation«. In all contexts the impact assessment is mostly used ex ante, at the stage of policy formulation, but it can also assist simplification programs and thus can be used ex post. Therefore the model of RIA, though somewhat similar, applied in different political contexts, following different procedures and given various understandings to the goals it is supposed to achieve results with not so much of a convergence of the legislative systems and the quality of legislation across Europe.

The UK is leading among the European countries in the introduction and use of impact assessments. In UK in the late 1990s The Prime Minister originally set the Better Regulation Executive the task of cutting

2 In combination with other tools, such as consultation, simplification, codes of conduct on legislative drafting, and initiatives to improve on the access to regulation.

3 http://www.hm-treasury.gov.uk/media/47C54/jirf_0104.pdf 
red tape so that businesses could be more productive and public services more efficient. Elements of this program were initially embodied in the Regulatory Reform Act 2001. RIA was claimed to enable policymakers to analyze the likely "economic, social, and environmental" impacts of any policy change and to evaluate the options for implementing it. For the government, the RIA was stated to be "a key tool in delivering better regulation and supporting its aim of regulating only when necessary". The National Audit Office (NAO) was ordered to conduct an evaluation of the quality and thoroughness of a sample of RIAs. And as Munday (2008) reports that sthe first review strongly supported their use as a means of fostering better regulation, whereas in a subsequent annual report expressed misgivings RIAs» ${ }^{4}$.

The improvement of the regulatory environment in the institutions of the European Union (EU) was taken when the European Union Institutions adopted the draft guidance recommendations contained in the Interinstitutional Agreement of December 1998. The purpose of this was to improve the quality of draft legislation. In 2003 a study for the Hellenic Presidency reported on the existence of RIA in seven member states, whilst the other six member states had at least pilot projects (Hellenic Presidency of the EU, 2003).

In 2004 RIA was officially recognized in the large majority of the EU15, and in new member states like Hungary and Poland (FORMEZ, 2004). In a study from May 2004 the Directorate General (DG) Enterprise from the European Commission (EC) revealed that fourteen "old" EU member states and significant number of the new ones: the Czech Republic, Slovakia, Slovenia, Estonia, Latvia, Hungary, Poland, and Bulgaria, considered the regulatory impact assessment as an important tool for good governance. However, the individual member states are still at varying stages with the implementation of their RIA processes. "The diversity of legal cultures, the various models of RIAs adopted and different levels of commitment towards RIAs can cause significant differences among the individual countries" (Stashanova, Pavel, \& Krapezh, 2007). However, number of scholars note that there is insufficient willingness of governments to incorporate RIA into existing policy-making processes. Even though the methodology is formally

4 Also see Evaluation of Regulatory Impact Assessments 2005/6, paral.6: http://www.nao.org.uk/publications/nao_reports/05-06/05061305.pdf

144 Uprava, letnik IX, 3/2011 
adopted or recognized in various policy documents in many cases, RIA has rather been interpreted as a business-oriented tool and an administrative burden than a complex empirical and analytical reference for political decision-making.

In every of the afore mentioned countries the requirement to apply exante impact assessment to draft legislation was introduced prior to the development of the Better Regulation documents, mostly as a reaction to pressure from the European Commission and other relevant international organizations.

\section{The Macedonian model of regulatory impact assessment}

As originally formulated in the United States, impact assessment is contingent on an orderly policy process with unitary actor to coordinate it and limited information gaps. This is argued to be the only appropriate policy making model where impact assessments are possible because in garbage-can policy processes problems are constantly reformulated by different political actors, solutions are changed frequently, and the competences of different departments are reshuffled or unclear.

The policy making process in Macedonia has been reformed since 2006 when a new Methodology for policy analysis and coordination was developed and adopted by the government followed by a series of capacity building efforts. The policy-making process envisaged in the new legal framework is an orderly process with one single actor to coordinate it (a Ministry, or the General Secretariat for horizontal issues) and limited information gaps. This model is close to the rational-synoptic policymaking conceptualized by Sabatier (1999) in numerous details. It includes five stages: (i) agenda setting or problem definition; (ii) policy analysis or identification of policy options and their evaluation; (iii) adoption of a policy option; (iv) implementation of a policy option; ( $v$ ) monitoring and evaluation. The new policy development framework sets out the basis for evidence based policy making as it is coupled with detailed guideline as well as manual for situation analysis. The process is coordinated by unitary actors and is characterized with inter-ministerial consultations.

Macedonia has initiated its better regulation policy through "regulatory simplification" as a tool for improving quality of legislation and decreasing administrative burden on businesses. This initiative was entitled 
"Regulatory Guillotine" 5 . The 2008 SIGMA Policy-Making and Coordination Assessment Report recognized that this regulatory simplification initiative had yielded significant results - 341 pieces of secondary legislation had been abolished, reflecting the views expressed by many government officials. The better regulation efforts were coupled with an effort to improve access to legislation for citizens and businesses facilitated through the Single Electronic Register of Regulations available at the government website.

During the financial crisis the government extended the implementation of the regulatory guillotine. This was facilitated by public consultations through which business associations became active in providing contributions to the legislative process, identifying laws or parts of laws that created barriers for doing business. The representatives of the Macedonian association of chambers of commerce and the Macedonian chamber of commerce testified the increasing trend of building legal capacity in their offices to be able to contribute constructive comments to the development of new legal acts to be responsive to the needs of the businesses. They hired lawyers, made surveys of opinion and submited surveys of gathered comments to the proposed laws representing the interests of their members. This was pertinent to the development of the consultative culture in policy making as well as presented a solid base for effective impact analysis provisioned under the RIA framework.

Regulatory Impact Assessment was first envisaged as a mechanism for assessing the options available for improving the legislation. Several factors have been decisive in supporting the introduction of Regulatory Impact Assessment. The academia was first to advocate the creation of "better regulation" units within the government. This was then corroborated with a detailed analysis of the possible implications of EU approximation, including the establishment of a framework policy for better regulation which was a criterion to be fulfilled by accession countries. This was followed with critical observations by SIGMA (2006) wthe policy development and legal drafting capacities in ministries remain weak«; and recommendations for "efforts ...(to) be concentrated on ministries to develop and ensure procedures and capacities for impact assessment«. Such recommendations stirred further debates among expert circles

5 More extensive information on the regulatory guillotine is available on: http://www.vlada.mk/?q=node/65

146 Uprava, letnik IX, 3/2011 
in the country on the introduction of Regulatory Impact Assessment as a mandatory phase in the policy-making process.

In 2008 the RIA requirement was explicitly introduced and made compulsory by the Rules of Procedure of the Government. This policy document formally provided that each ministry was required to identify laws to be subject to a RIA and to make a preliminary assessment of how extensive it should be (whether a preliminary/initial or a comprehensive/extensive RIA will be required) based on the principle of proportionality (OG RM no 36/2008, 51/08, 86/08,144/08, 42/09, $62 / 09,141 / 09,162 / 09,40 / 10)$. A regulatory impact assessment was to be undertaken for all legal acts (but not secondary legislation) proposed and prepared by the Government. Legal acts proposed and prepared by members of the Parliament as well as draft laws and amendments proposed by the citizens - making use of their right to legislative initiative - were not subject to regulatory impact assessments.

RIA for parliamentary proposals should be prepared using the same methodology as that used for government-supported legislation. The issue to be further explored is who in Parliament will conduct impact assessment. Current consultations with stakeholders have identified the Parliamentary institute as one possible option. Another option is the Government to prepare RIA and submit it to the Parliament together with its opinion on the draft law (envisaged in Art. 138 of the Rules of Procedure of the Parliament of the Republic of Macedonia).

RIA was introduced as part of an economic reform rather than of a public administration reform agenda. This is reflected in the fact that the process was managed by the General Secretariat's Sector for Economic Policies and Regulatory Reform (whose representatives participate in the work of the coordinative body (OG RM no.66/2009) as outlined in Table 1 - this body also comprises representatives of several other sectors of the General Secretariat such as Strategic Planning, ICT and the Policy-making and Coordination Sector) and that the Head of this Sector reports directly to the deputy Prime Minister of the Government in charge of economic issues. 
Regulatory Impact Assessment in Macedonia and Estonia:

Lessons (to be) Learned

\section{Table 1: Legal Framework for Impact Assessment in Macedonia}

\begin{tabular}{|l|l|}
\hline Aspects of Impact assessments & National Practice/Framework \\
\hline $\begin{array}{l}\text { Explicit policy, promoting regulatory reform } \\
\text { and regulatory quality improvement }\end{array}$ & $\begin{array}{l}\text { Rules of Procedures of the Government of } \\
\text { Republic of Macedonia adopted in 2008 }\end{array}$ \\
\hline Body responsible for the regulatory reform & $\begin{array}{l}\text { General Secretariat of the Government of } \\
\text { Republic of Macedonia }\end{array}$ \\
\hline $\begin{array}{l}\text { Legal act adopted by the government } \\
\text { which regulates the principles and } \\
\text { procedures of impact assessments }\end{array}$ & $\begin{array}{l}\text { Methodology for regulatory impact } \\
\text { assessment 2009 }\end{array}$ \\
\hline Written guidance on impact assessment & Manual for RIA \\
\hline Access to regulation & $\begin{array}{l}\text { Law on organization and work of the state } \\
\text { administration Art. 10 p. 1, as well as Art. } \\
71 / 68-a \text { from the Law on Government } \\
\text { regulates that draft laws should be } \\
\text { published on Ministry's web sites }\end{array}$ \\
\hline $\begin{array}{l}\text { Consultation } \\
\text { Responsible for guaranteeing impact } \\
\text { memorandum accompanying draft laws }\end{array}$ & $\begin{array}{l}\text { Regulated in the Law on Organization } \\
\text { and Work of the State administration Art. } \\
10, \text { p.2 and operationally planned to be } \\
\text { achieved through ENER }\end{array}$ \\
\hline Categories of impact assessments & $\begin{array}{l}\text { Sector for Economic Policy Reform and } \\
\text { Regulatory reform of the General } \\
\text { Secretariat of the Government of the } \\
\text { Republic of Macedonia (i.e. the } \\
\text { coordinative body comprised of } 8 \\
\text { representatives from all the sectors of the } \\
\text { General Secretariat) as a coordinator, } \\
\text { that does not conduct extensive quality } \\
\text { control }\end{array}$ \\
\hline Thention and quality control unit
\end{tabular}

Source: Authors' summary of the legal framework regulating RIA in MK using the framework fro Mandelkern Group

The use of separate forms for RIA is foreseen to further fragment the policy-making processes of which RIA should be part and therefore the SIGMA recommendations are to integrate the RIA requirements into the rules for policy-making. Along with the integration of RIA into the regular policy process, all aspects of policy co-ordination should be unified within the Sector for Policy Analysis and Co-ordination in the General Secretariat. Fragmentation of similar functions within the General Secretariat should be avoided (SIGMA, 2006).

148 Uprava, letnik IX, 3/2011 
The requirement for impact assessments has been operational since January 2009 and since then ministries generally comply with the requirement ${ }^{6}$, but they do not conduct an in-depth impact analysis. The Government, i.e. the General Secretariat, is particularly supportive for further improvement of the RIA process, which is to be commended. ${ }^{7}$

The Methodology for Regulatory Impact Assessment (as well as other legal acts) contains provisions allowing for consultations with citizens through public discussions and interactions with civil society groups ${ }^{8}$. However, as these consultations are not compulsory, they rarely take place in practice. Furthermore, the procedure for such consultations is not described in sufficient detail. For instance, there is no mention of the situation when a draft piece of legislation as subject of consultations should be made accessible to the public, in what form the contributions from consulted parties should be collected, or how the reporting on these consultations is to take place.

With the adoption of the Law on Free Access to Information (OG RM No. 13/2006; 86/2008 and 6/2010) and changes to the Rules of Procedure of the Government - which requires each Ministry to publish its draft legislation on its own website as well as on the Single National Registry of Regulations - consultations with the stakeholders have become more accessible to the public at large. But despite the considerable progress made in the past three years in making information and draft legal texts available to the public the question of how to enhance participation of non state actors (such as civil society associations, interest groups, the academia, research centers and the media) in policy-making still remains.

The general framework for the preparation of laws includes a procedure for inter-ministerial consultations. The inter-ministerial consultations are concerned with the collection of opinions on the draft

6 It is said that $95 \%$ of all new legislation is accompanied with RIA forms, which in practice, as discussed with the interlocutors may rather be considered as formal filling in RIA forms.

7 In accordance with the information obtained in the course of the preparation of this analysis, it is envisaged that the analysis of the introduction and the quality of the RIA should be performed in the General Secretariat through a project financed by the British Embassy.

8 Law on the Organization and the Work of the State Administration Bodies Ar. 10, pg. 2 and 3 . 
legislation from the relevant ministries and agencies, while public consultations aim at gathering views to be fed into the design of the regulation as well as the assessment of its possible impact on the concerned parties. The inter-ministerial consultations are carried out on a routine basis but late in the policy-making process. They are most often used for collecting opinions on a draft law when a text has already been drafted; the opinions collected are therefore mostly about issues of nomotechnical nature with a focus on linguistic issues or formal requirements such as compliance of the draft with the legal framework.

Impact assessments have three main components (social, economic, environmental), which broadly correspond to those outlined in the EU guidelines on impact assessment (European Commission, 2002). However, these components are not interpreted in a uniform manner (see Table 2 for an overview).

It appears that the Manual for RIA is a helpful tool for explaining the need for RIA in the policy-making process. However it seems that it does not provide sufficient guidance as to the ways in which RIA analysis may be conducted, which explains partly why the line Ministries so far just fill in the RIA forms and have not attached to any newly proposed legal act a full and realistic impact analysis of the proposed document.

In conclusion, from the overview and analysis presented above one might conclude that there is political will in support of better regulation as evidenced in a series of declaratory documents setting up the formal legal framework for the conduct of regulatory impact assessments and in proforma filling of RIA forms when new legislation is proposed. There is, however, an over-emphasis on the fiscal implications and administrative burden, which is in line with the general understanding of the RIA's role. This, together with the fact that RIA was mostly conceived as part of an economic reform package, has resulted in RIA being confined to specific sectors instead of being made fully part of the general policy-making. The current system therefore still falls short of exploring the full potential of RIA as a tool for better regulation. In particular, progress is still needed with regard to the quality of the assessments. There appears to be a need for clear guidelines on how to conduct impact assessments. 
Table 2: Components of RIA in Macedonia

\begin{tabular}{|l|l|}
\hline Components of impact assessment & National Framework/Practice \\
\hline Identification of rationale & RIA form \\
\hline $\begin{array}{l}\text { Justification for intervention and } \\
\text { identification of options for intervention }\end{array}$ & Not specifically asked for \\
\hline Category social impact assessment & $\begin{array}{l}\text { Not included in the Memorandum as a } \\
\text { separate heading; no evidence of being } \\
\text { made till date. Exists as a subheading in } \\
\text { the RIA forms }\end{array}$ \\
\hline Category economic impact assessment & $\begin{array}{l}\text { Exists as a subheading in the RIA forms, } \\
\text { stressed through the Fiscal implications } \\
\text { form }\end{array}$ \\
\hline Rategory environmental impact & $\begin{array}{l}\text { Exists as a subheading in the RIA forms, } \\
\text { Required in the Law on Environmental } \\
\text { arotection }\end{array}$ \\
\hline assessment & $\begin{array}{l}\text { No direct requirement in the methodology, } \\
\text { but for environmental impact assessments } \\
\text { the practice is to engage experts in the } \\
\text { preparation of the report }\end{array}$ \\
\hline Consultations & $\begin{array}{l}\text { Envisaged public consultations which are } \\
\text { lacking in practice; Inter-ministerial } \\
\text { consultations are used and generate } \\
\text { opinions on the legal alignment; instead of } \\
\text { evaluation of options/solutions/policies }\end{array}$ \\
\hline $\begin{array}{l}\text { No body is assigned specifically to provide } \\
\text { monitoring and evaluation of the quality of } \\
\text { the RIA process }\end{array}$ \\
\hline and evaluation
\end{tabular}

Source: Authors' summary of the legal framework regulating RIA in MK

\section{The Estonian model of regulatory impact assessment}

In 1993 the Estonian Riigikogu (the Parliament) has amended its "Rules for Draft Regulation in the Legislative Proceedings"9 to include a Regulatory Impact Assessment as a necessary step in the process of law making. The Rules regulate in detail the procedures to be followed in cases when the Riigikogu acts as an initiator for enactment of legislation. RIA could be initiated from any of the existing standing committees in the

9 "Rules for Draft Regulation in the Legislative Proceedings" are accessible at http://www.riigikogu.ee/rva/ecprd/html/appendix_A-12.html last time accessed at 31.08.2010. 
Riigikogu, however, the most active is the Department of Economic and Social Information - DESI (Kasamets 2001, p. 73). The Riigikogu has a separate budget allocation specifically dedicated for conducting RIA. The Secretary General is normally responsible for the outsource management whereby RIA is usually conducted by either consultant firms or universities (Kasamets 2001, p. 73). Political parties can also order a RIA to be conducted by the Department for Economic and Social Information albeit the RIA carried out by DESI is only partial. There are other modalities of initiating RIA in the Riigikogu bet these two, in particular the former modality is the most frequent one.

The articles 42-54 of the Rules for draft regulation (2001) regulate the procedure of passing a legal act in the Parliament whereby apart from explanation the reasons and the substance of the propositions made in the draft the initiator is required to provide a ssurvey of regulatory impacts arising from entry into force of the Act« ${ }^{10}$. Each of the legal acts proposed in the Parliament must be accompanied by an explanatory note which contains a total of ten subsections.

Article $49^{11}$ outlines 7 different impacts that could result from enforcement of the legal Act among which are: demographic and social consequences; impact on national security and international relations; impact on economy, including entrepreneurship, employment and inflation; impact on human and natural environment; impact on organization of work of state or local government agencies, including growth of or increase in the public sector; other consequences arising out of the passage of an Act.

In addition, a complete list of references must be attached to the explanatory note. Article $50^{12}$ provides for the need to assess the fiscal implications arising from the implementation of the act. The fiscal implications should include direct one-time and annual expenses but also implications on the budgets of local governments, other indirect expenses and expected income. The Parliament has also provided guidelines containing recommendations and examples aimed to support the institutionalization of RIA and its embedment in the policy making process.
10 ibid
11 ibid
12 ibid

152 Uprava, letnik IX, 3/2011 
Table 3: Legal Framework for Impact Assessment in Estonia

\begin{tabular}{|l|l|}
\hline Aspects of Impact assessments & National Practice/Framework \\
\hline $\begin{array}{l}\text { Explicit policy, promoting regulatory reform } \\
\text { and regulatory quality improvement }\end{array}$ & $\begin{array}{l}\text { Rules for Draft Regulation in the Legislative } \\
\text { Proceedings (1993) }\end{array}$ \\
\hline Body responsible for the regulatory reform & Riigikogu and Government of Estonia \\
\hline $\begin{array}{l}\text { Legal act adopted which regulates the } \\
\text { principles and procedures of impact } \\
\text { assessments }\end{array}$ & $\begin{array}{l}\text { Parliaments Rules for draft regulation } \\
\text { (2001, 2005) }\end{array}$ \\
\hline $\begin{array}{l}\text { Government Technical Rules for drafts of } \\
\text { legislative Acts (1996, 2000) }\end{array}$ \\
\hline $\begin{array}{l}\text { Responsible for guaranteeing impact } \\
\text { assessment information in the explanatory } \\
\text { memorandum accompanying draft laws }\end{array}$ & $\begin{array}{l}\text { Secretary General of Riigikogu } \\
\text { Secretary General of Government of EE }\end{array}$ \\
\hline $\begin{array}{l}\text { Outsourced to consulting firms } \\
\text { Department for Economic and Social } \\
\text { Information }\end{array}$ \\
\hline $\begin{array}{l}\text { Categories of impact assessments } \\
- \text { demographic and social consequences; } \\
\text { - impact on national security and } \\
\text { international relations; } \\
- \text { impact on economy, including } \\
\text { entrepreneurship, employment and } \\
\text { inflation; } \\
- \text { impact on human and natural } \\
\text { environment; } \\
- \text { impact on organization of work of state } \\
\text { or local government agencies, including } \\
\text { growth of or increase in the public sector; } \\
\text { other consequences arising from the } \\
\text { passage of Act }\end{array}$ \\
\hline
\end{tabular}

Source: Authors' summary of the legal framework regulating RIA in EE

Apart from the Parliament the Government of Estonia has also designed a separate document "Technical Rules for Drafts of Legislative Acts" prescribing the procedures to be followed by the Ministries when drafting Legal Acts, however, the content of the methodology is not different from the one elaborated above. Impact assessments have become obligatory for Government Ministries based on the Government "Technical Rules" in 1996 and were amended in 2000. The political commitment to conducting impact assessments as a tool that facilitates the better regulation agenda has been on the rise ever since. This political 
commitment has been substantiated by signing a "Coalition Agreement" containing 17 promises related to IA (Kasamets, 2005) ${ }^{13}$.

The Coalition Agreement also mentions the importance for simplified regulatory procedures which are expected to have a positive impact on starting up businesses and to downsize the time consuming activities for businesses when dealing with local authorities. In the section on Legal policy the agreement adheres to codification of a number of legislative branches and more so the eighth objective under the same section foresees to "create a system for evaluation of the impact of legislation. A revision of the effective legislation shall be carried out and unnecessary legislation shall be repealed « ${ }^{14}$.

The Coalition Agreement has clearly provided for an effective impetus in raising the political value of RIA in the overall policy process and in the absence of an official separate document on Better regulation acts as an implicit strategy on the side of the Government (OECD 2007, p. 25). Since 2005, the Ministries have been provided with the opportunity to adjust the main methodology foreseen in the Technical Rules according to the peculiarities of the policy field for which they are responsible (Kasamets, 2005).

Studies conducted at different time-periods document a notable positive development in the implementation of RIA. The first most comprehensive study conducted in 2004 aimed to analyze the gap between the quality of the "regulatory impact assessments" and the requirements officially prescribed by the Technical Rules (Kasamets, 2004). The analysis made an overview of a sample of 651 laws in the period between 1998 and 2003. From the table 4 one can note that on a more general level the Ministries perform much better against all six criteria as opposed to the Parliament. This should not be a surprise considering the human resources capacity of the Governments in almost all countries compared to the Parliament. As for the performance against the individual impact categories the "analysis of conformity to EU legislation" ranks the highest, followed by "impact on state budget" then "impact on public administration", "socio-economic impacts" and

13 Presentation "Quality of legislation and the role of impact assessments" available at http://aare-kasemets.planet.ee/koolitus/AKasemets_Legislation_Impact_Analysis_ 111005 bru.pdf, last time accessed at 31.08.2010.

$14 \mathrm{http}: / /$ www.valitsus.ee/? $\mathrm{id}=1468$, last time accessed at 31.08.2010.

154 Uprava, letnik IX, 3/2011 
"references on studies and consultations" as the last. Socioeconomic impacts, in contrast to the previous case, rank the highest in the case of laws initiated by the Parliament, while the rest of the impacts analyzed rank the same.

Table 4: Results of the analysis of explanatory memoranda to draft Acts. Followup 1998-2003. Accordance with normative requirements: positive evaluation of draft Acts in categories F-K

\begin{tabular}{|c|c|c|c|c|c|c|}
\hline $\begin{array}{l}\text { Initiator of draft } \\
\text { Act } \\
\text { ( } n=\text { number of } \\
\text { draft Acts } \\
\text { chosen for } \\
\text { normative } \\
\text { analysis) }\end{array}$ & \begin{tabular}{|r}
$F$ \\
Impact on \\
state \\
budget \& \\
public \\
expendi- \\
tures
\end{tabular} & $\begin{array}{r}G \\
\text { Impact on } \\
\text { public } \\
\text { admi- } \\
\text { nistration } \\
\text { \& services }\end{array}$ & $\begin{array}{r}\mathrm{H} \\
\text { Impact on } \\
\text { socio- } \\
\text { econ. } \\
\text { conditions } \\
\text { of target } \\
\text { groups }\end{array}$ & $\begin{array}{r}\text { I } \\
\text { Informing } \\
\text { and } \\
\text { involvement } \\
\text { of target } \\
\text { groups / } \\
\text { NGOs }\end{array}$ & $\begin{array}{l}\text { J } \\
\text { References } \\
\text { on studies, } \\
\text { databases, } \\
\text { \& opinions }\end{array}$ & $\begin{array}{r}K \\
\text { Analysis of } \\
\text { conformity } \\
\text { to EU } \\
\text { legislation }\end{array}$ \\
\hline $\begin{array}{l}\text { Ministries } \\
(n=383)\end{array}$ & 272 & 198 & 180 & 86 & 99 & 284 \\
\hline $\begin{array}{l}\text { Positive } \\
\text { evaluation - \% }\end{array}$ & $71 \%$ & $52 \%$ & $47 \%$ & $24 \%$ & $26 \%$ & $74 \%$ \\
\hline $\begin{array}{l}\text { Parliament } \\
(n=268)\end{array}$ & 91 & 48 & 113 & 16 & 27 & 34 \\
\hline $\begin{array}{l}\text { Positive } \\
\text { evaluation - \% }\end{array}$ & $34 \%$ & $18 \%$ & $42 \%$ & $6 \%$ & $10 \%$ & $13 \%$ \\
\hline $\begin{array}{l}\text { Total } \\
(\mathrm{n}=651)\end{array}$ & 363 & 246 & 293 & 120 & 126 & 318 \\
\hline $\begin{array}{l}\text { Positive } \\
\text { evaluation - \% }\end{array}$ & $56 \%$ & $38 \%$ & $45 \%$ & $18 \%$ & $19 \%$ & $49 \%$ \\
\hline
\end{tabular}

Sources: A. Kasemets, K. Vallimäe 1999 (1998, n=152); S. Soiver, M. Avamere, A. Kasemets 2000 (1999, n=142); K. Mikk 2002 (2001a, n=132); J. Ender, M. L. Liiv 2002 (2001b, n=100); K. Kasemets (2003, n=125); Kasamets 2004

Another study conducted just recently unambiguously documents significant improvement in the quality of RIA statements, implementation and overall policy process. Staronova (2010) has compared four countries having communist background as a common denominator, but presently all of them are members of the European Union and thereby share the same challenge with regards to "good governance". Analyzing the reasons for the clear advancement in Estonia with regards to RIA and overall policy making Staronova points out to the strong political centre located in the State Chancellery which acts in the capacity of a coordinator of the overall policy making process, the alignment of proposed laws with the strategic documents and also oversees the quality 
of RIA statements (Staronova 2010, p. 16). Concerning the methods used for conducting impacts assessment currently $1 / 3$ of the impacts assessed contain costs and benefits expressed in quantified measures ${ }^{15}$. The process has been supported by integrated guidelines in 2005 (updated in 2009) followed by an ongoing training program (2009-2011) for civil servants $^{16}$. In addition the officials have developed an e-learning too ${ }^{17}$ targeted at civil servants which is accessible at any time.

\section{Comparing the RIA experiences in Macedonia and Estonia}

In Macedonia as in Estonia the RIA framework was adopted as an effort to approximate the Macedonian / Estonian legislation and legislative processes with those of the EU. Yet, several important differences exist.

In both countries the RIA process encompasses categories that broadly correspond to the EU guidelines on impact assessment, to cover the economic, environmental and social impacts of a proposal (European Commission, 2002). However, in terms of scope the obvious distinction between the two is that the Estonian RIA apart from the three categories of impact mentioned above includes impact on budget, on public administration and non-state actors. With this the RIA model employed in Estonia is assessing the influence new legislation would have on all aspects of society. The Macedonian model is therefore narrower.

Considering that in Estonia the RIA can be initiated for laws that are developed both in Parliament and in Government, and in Macedonia for the time being RIA is not extended to the Parliament, but is performed just

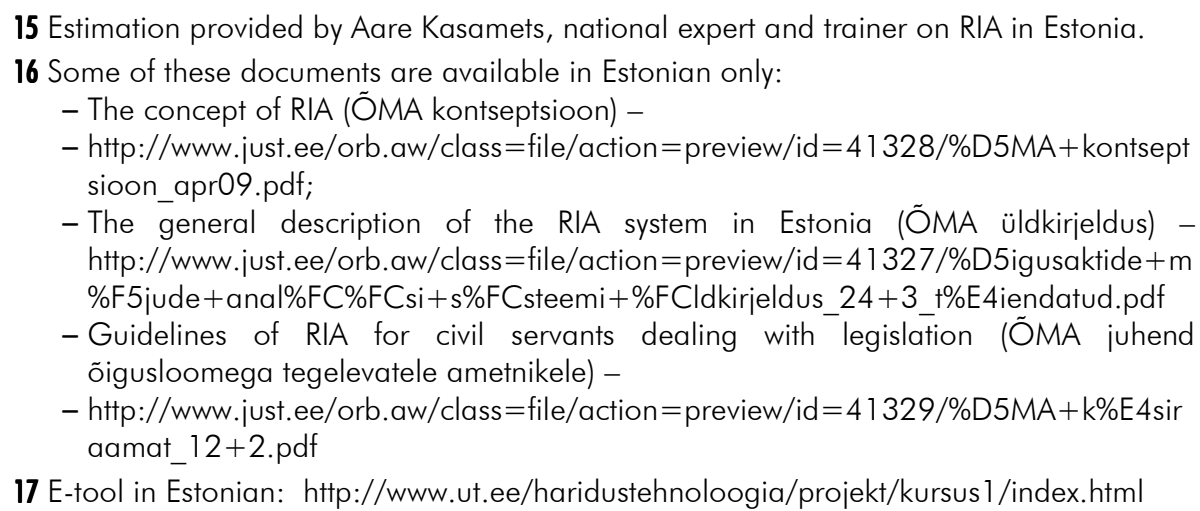

156 Uprava, letnik IX, 3/2011 
in Government procedure for law making, one might also argue that the Estonian model is more developed in comparison to the Macedonian model. This argument also applies to the methodology for conducting RIA which in Macedonia is limited to the different stages in the RIA process (screening, initial RIA and in-depth RIA) whereas in Estonia it encompasses the research and analytical methods that should applied in the RIA process.

In the Estonian model the Department for Social and Economic Information is authorized to perform only partial RIA, whereas the fullfledged analysis should be undertaken by external body (consulting company and/or university). In the Macedonian model the Ministries are the only authorized bodies to conduct RIA (except for the environmental RIA which under the Law on environment should be outsourced). Taking in consideration the capacities, the workflow and available resources Ministries have in Macedonia it is only feasible to expect that they will perform only partial RIA. In this respect the Estonian model seems to have bigger potential to provision and deliver analysis of the regulative impact, as the two evaluations mentioned in the previous chapter show. In Macedonia the model itself makes the Ministries just to fill in the RIA forms.

From the analysis in the previous chapters, one important similarity in both cases can be observed in relation to the political commitment for better regulation. In Estonia this is demonstrated through the Coalition agreement for RIA, whereas in Macedonia through the "regulatory guillotine", a campaign for simplification of regulation.

\section{Possible lessons (to be) learned}

The two case studies show that the RIA process has been paralleled with the process of political transformation and facilitated by the eurointegration process. The euro integration process brought about an immense influx of regulations that had to be integrated in the national legal systems. In Estonia RIA was therefore used to minimize the discrepancy between the need to adopt European regulations and its disparity with the under-developed socio-economic context. The rapid adoption of EU legislation in Macedonia is causing much of the same problems. RIA therefore offers an opportunity for awareness of the need to manage the process by considering more carefully the appropriateness of foreign policy solution to the peculiarities of the Macedonian 
socio-economic context. It was due to mechanical adoption of EU legislation in Estonia that caused as Narits (2001) perfectly points out an internally discordant legal system that does not function properly. In that regard, as in the case of Estonia "Regulatory Impact Assessments" in Macedonia must be seen as a potential tool for overcoming the aforementioned challenge. For this to emerge, a political commitment to RIA is necessary, as well as full integration of the RIA process in general policy making in Macedonia is needed.

In Macedonia the development of the RIA system is at its beginning and though analytical methods are not defined most laws are accompanied with RIA forms. This was not an exception for the Estonian model at the beginning. The Estonian case shows that the RIA model evolves. Considering Macedonia is at the beginning stage of the development of the Macedonian RIA model and taking in account the above analysis, these are the areas where we see room for improvement:

1. Pushing for full implementation of the RIA provisions and preparation of impact assessment analysis, rather than just filling the RIA forms, will put an emphasis on quality of laws in the preparatory stages. This might be achieved, as it is the case in Estonia, through outsourcing of analysis to think-tanks, consulting firms and universities.

2. If the above is not financially sustainable, then developing an institutional capacity for conducting RIA should be a priority. The Estonian case offers a model of establishment of Department for Economic and Social Information that performs partial RIA. Another model is development of an institutional network, departments in every Ministry and a central department in the General Secretariat that will conduct and check the quality of RIA (Page, A. \& Risteska, M. 2010).

3. Introducing a regulatory impact assessment for laws developed and proposed by the members of Parliament of the Republic of Macedonia. As it is the case with Estonia the Parliament must become one of the driving forces of the RIA process as this opens further opportunities for introduction of ex-post RIA and strengthening the oversight role of the legislative body.

4. Making the General secretariat a coordinator for the overall policy making process and strengthening the capacity of its Sector 
for policy analysis and coordination to undertake full coordination of the RIA process similarly to the role of the State Chancellery in Estonia.

Marija Risteska holds PhD in political science. She is the founder and works as Senior Analyst at the Centre for Research and Policy Making. Her research work is in the area of public administration reform, public management, good governance, policy transfer and European integration. She teaches public policy, comparative public administration and public management at NY College in Skopje. Besides numerous policy studies on European integration of Macedonia, good governance in health, education, gender, and migration, Marija Risteska has coedited the book "European Law for SMEs". She has contributed to four specific public sector reforms in Macedonia on public policy development, strategic planning, and better regulation reforms. Marija Risteska has 10 years of consulting experience with the EU and all UN agencies. She managed a program in NDI, and the education portfolio of the World Bank in Macedonia. 


\section{References}

\section{Books and papers}

- He'ritier, A., Kerwer, D., Knill, C., Lehmkuhl, D., Teutsch, M. \& Douillet, A.C. (2001). Differential Europe. The European Union Impact on National Policymaking. Lanham, MD: Rowman \& Littlefield.

- Hood, C., Rothstein, H. \& Baldwin, R. 2001. The Government of Risk. Understanding Risk Regulation Regimes. Oxford: Oxford University Press.

- Jacobs\&Associates. 2006. Current Trends in Regulatory Impact Analysis: the Challenges of Mainstreaming RIA into Policymaking. Washington DC: Jacobs\&Associates.

- Kasamets, A. (2001). Impact Assessment of Legislation for Parliament and Civil Society: a Comparative Study. Legal and Regulatory Impact Assessments of Legislation (47-96). Talin: ECPRD.

- Kasamets, A. (2004). The use of RIA information in the explanatory memoranda of draft acts: a precondition for knowledge-based legislation and public adminstration.

- Kirkpatrick, C. \& Parker, D. (2003). Regulatory Impact Assessment: Developing its Potential for Use in Developing Countries. Manchester: Centre on Regulation and Competition.

- Lepa, R, Illing, E., Kasemets, A., Kallaste, E. \& Lepp, U. (2004). Engaging Interest Groups in Decision-making Processes. Tallinn: Praxis. English version available at: http://www.praxis.ee/data/kaasamine_eng_9_03.pdf.

- Munday, R. (2008). In theWake of 'Good Governance': Impact Assessments and the Politicization of Statutory Interpretation. Modern Law Review 71 (3), 385-412.

- Narits, R. Assessment of the impact of draft legislation: the problems in and opportunities for ensuring the quality of law-making and legal acts Estonian experience.

- Page, A., Risteska, M. \& Spasovska, N. (2010). Monitoring of the Implementation and Ex-post Evaluation of the Legislation - Comparative Experiences, Options and Capacities, OSCE.

- Radaelli, C. M. (2005). How context matters: regulatory quality in the European Union. Journal of European Public Policy 12(5), 924-943.

- Radaelli, C. M. (2005). Diffusion without convergence: how political context shapes the adoption of regulatory impact assessment. Journal of European Public Policy 12(5), October 2005, 924-943.

- Renda, A. (2006). Impact Assessment in the EU. The State of the Art and the Art of the State. Brussels: Centre for European Policy Studies. 
- $\quad$ Risteska, M. (2004). The EU BEST report and its application in Macedonia. In Risteska, Zahorka, Dimovska et al. (eds.) EU Law for SMEs. Skopje.

- Staronová, K. (2007). The quality of information on impact assessment in explanatory memoranda to draft legislation: the case of Slovakia. In: Clive George and Colin Kirkpatrick (Eds.). Impact Assessment and Sustainable Development: European Practice and Experience (230-255). Cheltenham: Edward Elgar Publishing.

- Staronová, K. (2010). Regulatory Impact Assessment:Formal Institutionalization and Practice. Journal of Public Policy, 117-136.

- Staronová, K., Pavel, J. \& Krapež, K. (2007). Piloting regulatory impact assessment: a comparative analysis of the Czech Republic, Slovakia and Slovenia. Impact Assessment and Project Appraisa/ 25(4), December 2007, 271-280.

- Trnka, D. (2005). Better Regulation in the Transition Economy, Case of the Czech Republic. OECD GOV Working Party on Regulatory and Reform, Recent Regulatory Reform activities in Hungary. Submission by the Hungarian delegation, Public Governance Committee, 28 September.

- Vilms, K. (2003). Sociological and public opinion research as refelction for the Parliament and the civil society. Ageing societies, new sociology (1-11). Murcia: ESA.

- Vilms, K. (2004). The use of socio-legal information in the draft acts' explanatory memoranda: a precondition for good governance. CEE Countries Inside and Outside the EU: Avoiding a New Divide (1-12). Vilnius: NISPAcee.

- Vilms, K. (2006). Better Regulation in Estonia. OECD. 


\section{Reports}

- $\quad$ AUBG (2004). The use of RIA information in the explanatory memoranda of draft acts: a precondition for knowledge-based legislation and public adminstration. Implementation of Regulatory Impact Assessmenst: Best Practices in Europe (69-91). Blagoevgrad: AUBG.

- DG Enterprise (2004). Indicators of Regulatory Quality. Centre for European Studies, University of Bradford.

- European Commission (2002). Impact Assessment in the Commission: Guidelines. Available at: http://europa.eu.int/comm/secretariat_general/ impact/index_en.htm.

- European Commission (2004). Who is doing what on better regulation at EU level - organization charts. Commission Working Document compiled by the Secretariat General TFAU-2 (Task Force Future of Union). Brussels.

- European Centre for Parliamentary Reasearch and Documentation (2001). Talin: Riigikogu.

- FORMEZ (2004). A comparative analysis of RIA in ten EU countries. Report prepared for the Directors of Better Regulation. Dublin, May 2004. Availabile at: http://www.betterregulation.ie.

- GfK Custom Research Baltic Estonia (2008). Measures supporting the employment of the disabled. Evaluation. Talin: Ministry of Social Affairs of Estonia.

- Hellenic Presidency of the EU, Ad Hoc Group of Experts on Better Regulation (2003). Report to the Ministers responsible for Public Administration. Mimeo, Athens, May.

- Mandelkern Group Report (2001). Final Report. Brussels: European Commission. Available at: http://www.cabinetoffice.gov.uk/regulation/docs/ europe/pdf/mandfinrep.pdf.

- Murakas, R. et al. (2007). Impact Assessment of the Youth Programme in Estoni 2000-2006. Talin: Tartu University.

- National Audit Office (2005). Evaluation of Regulatory Impact Assessments: Compendium Report 2004-2005. London: NAO.

- $\quad$ OBSE/ODIHR Noembri 2007, Izrabotka na zakoni i regulatoren menadžment vo Makedonija - Procena.

- $\quad$ OBSE Nabljuduvačka misija vo Skopje - Oddel za reforma na javnata administracija. "Istražuvanje za decentralizacijata", septembri 2007.

- $\quad$ OECD (1997) Regulatory Impact Analysis. Best Practices in OECD Countries, Paris: OECD Publications. 
- OECD (2002). Regulatory Policies in OECD Countries: From Interventionism to Regulatory Governance. Paris: OECD Publications.

- OECD (2007). Regulatory Management Capacities of Member States of the EU that Joined the Union on 1 May 2004: Sustaining Regulatory Management Improvements through a Better Regulation Policy.

- Sigma (2001). Improving policy instruments through impact assessment. Sigma Paper No. 31. Paris.

- SIGMA (2004). Support for Improvement in Governance and Management 2004. Regulatory management capacities of new (EU) member states: country report Slovenia. Final report, prepared by the Ministry of Public Administration.

- Sigma assessment report, External audit, izraboten vo Juni 2007.

- Sigma (EC/OECD) May 2008, Policy making and co-ordination Assessment

\section{Laws}

- Code of Good Practices on Involvement. Available at: http://www.ngo.ee/11583.

- Decision of Estonian Parliament Approval of Estonian Civil Society Development Concept. Available at: http://www.ngo.ee/7337.

- Delovnik za rabota na Vladata na Republika Makedonija (Prečisten tekst). Služben Vesnik na Republika Makedonija, br.58/06.

- Development Plan of the Ministry of Justice until 2012. Available at: http://www.just.ee/34654.

- Environmental Monitoring Act (consolidated text May, 2005). Available at: http://www.legaltext.ee/en/andmebaas/ava.asp? m=022.

- Government of the Republic Act (consolidated text December, 2005). Available at: http://www.legaltext.ee/en/andmebaas/ava.asp?m=022.

- Law on Free Access to Information. Zakon za sloboden pristap do informacii Služben Vesnik na Republika Makedonija, br.13/06.

- Law on organization and work of public bodies. Official Gazette of Republic of Macedonia, no. 58/2000 and 44/2003.

- Methodology for policy analysis and coordination. Official Gazette of Republic of Macedonia, no. 52/06.

- Methodology for regulatory impact assessment. Official Gazette of Republic of Macedonia, no. 37/2008. 
- Methodology for strategic planning and preparation of the annual work program of the Government of Republic of Macedonia. Official Gazette of Republic of Macedonia, no. 124/08.

- $\quad$ ÕMA juhend õigusloomega tegelevatele ametnikele. Availabile at: http://www.just.ee/orb.aw/class=file/action=preview/id $=41329 / \% D 5 M A+$ k\%E4siraamat_12+2.pdf.

- ÕMA kontseptsioon. Availabile at: http://www.just.ee/orb.aw/class=file/action = preview $/$ id $=41328 / \%$ D5MA+ kontseptsioon_apr09.pdf.

- $\quad$ OMA üldkirjeldus. Availabile at: http://www.just.ee/orb.aw/class=file/action=preview/id =41327/\%D5igusa

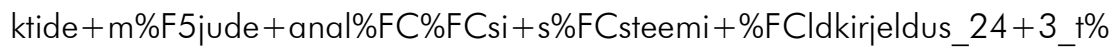
E4iendatud.pdf.

- $\quad$ Procedure for Implementation of Sub-programmes of National Environmental Monitoring Programme. Regulation No. 71 of the Minister of the Environment of 7 December 2006. Available at: http://www.legaltext.ee/en/andmebaas/ava.asp? $\mathrm{m}=022$.

- Quality of legislation and the role of impact assessments (presentation). Available at: http://aare-kasemets.planet.ee/koolitus/AKasemets Legislation_Impact_Analysis_111005bru.pdf. Last time accessed: 31.08. 2010

- Riigikogu Rules of Procedure and Internal Rules Act. Available at: http://www.riigikogu.ee/?rep_id =799356

- Rules of procedures of the Government of Macedonia. Official Gazette of Republic of Macedonia, no. 36/08.

- Technical rules for drafts of legislative acts. Available at: http://www.legaltext.ee/en/andmebaas/ava.asp? $\mathrm{m}=022$.

- http://www.ut.ee/haridustehnoloogia/projekt/kursusl/index.html

- $\quad w w w . o s a l e . e e$

- $h t t p: / / p e t i t s i o o n . e e /$

- $\quad h t t p: / / w w w . m k m . e e / 8252 /$

- http://aare-kasemets.planet.ee/koolitus/AKasemets_Legislation_Impact_ Analysis_111005bru.pdf 
POVZETEK

\section{PREVERJANJE UČINKOV PREDPISOV V \\ MAKEDONIJI IN ESTONIJI - KAJ SE IZ TEGA LAHKO NAUČIMO}

Ključne besede: EU, RIA, učenje na primerih, Estonija, Makedonija

Upoštevajoč, da je zakonodaja (primarna in sekundarna) najpogosteje uporabljeno orodje za oblikovanje politike, in da država v odgovor na finančno krizo $\vee$ letih 2008-2009 globlje posega $\vee$ urejanje poslovnega okolja, predstavlja članek uporabo preverjanja učinkov predpisov (RIA), ki je pomemben element krožnega toka oblikovanja celostne politike in omogoča raziskovanje vplivov zakonodaje na različne dele družbe, tudi poslovne. To orodje analize politike uporablja večina članic EU in tudi države, ki si želijo članstva, kot na primer Makedonija. Ker je RIA $\vee$ Makedoniji še $\vee$ povojih, je avtorica $\vee$ svoji študiji primera uporabila Estonijo ter izluščila nauke, ki se jih Makedonija lahko nauči od Estonije. Analiza pokaže, da je bila RIA v Makedoniji uvedena v sklopu ekonomskih reform. Posledično se uporablia samo na določenih sektorijh, namesto da bi bila popolnoma vključena $v$ oblikovanje politike. Trenutni sistem torej ne uporablja vseh možnosti, ki jih ponuja RIA kot orodje za boljši nadzor in upravljanje. Koordinacija vpeljevanja RIE, razširitev uporabe in metode za njeno uporabo in delovanje, vse to so področja, kjer Makedonija lahko izboliša svojo politiko, če se opira na primer Estonije. 